\title{
Prevalence of CD34, CD326 and STRO-1 expression in gastric precancerous and cancer samples: A preliminary study
}

\author{
Mehdi Mohammadi ${ }^{1}$, Ali Jalili ${ }^{1,2}$, Bahram Nikkhoo ${ }^{1}$, Fardshad Sheikhesmaieli ${ }^{2}$ \\ 1.Cancer and Immunology Research Center, Kurdistan University of Medical Sciences, Sanandaj, Iran, Tel: 087- \\ 33664658,Email: ali130@gmail.com, ORCID CD: 0000-0002-1833-4928 \\ 2.Liver and Digestive Research Center, Kurdistan University of Medical Sciences, Sanandaj, Iran.
}

\begin{abstract}
Background and Aim; Gastric cancer is one of the most common cancers in the world. It is well-known that Helicobacter pylori (H. pylori) plays a crucial role in its pathogenesis. Recent studies have shown that $H$. pylori infection leads to the migration of bone marrowderived mesenchymal stem cells (BM-MSC) into the gastric tissue and their resultant change into gastric cancer in animal models. However, the existence of these cells in human gastric cancers has not yet been studied.

Materials and Methods: We selected 10 each precancerous sample (dysplasia and metaplasia) and 15 gastric cancers from the pathology department of Toheed Hospital in Sanandaj.. All of the samples were stained by CD34, CD326, and STRO-1 antibodies and immunohistochemistry technique. Pathologic diagnosis was made by an expert pathologist.

Results: CD34 was expressed only on endothelial cells of all samples. CD326 was expressed at a low level in precancerous samples, but its expression was much higher in cancer samples. In contrast, STRO-1 antigen was not detected in any of the samples.

Conclusion: CD34 and CD326 were expressed in gastric cancer samples. However, STRO-1 antigen which is a specific marker for BM-MSC was not detected in gastric precancerous and cancer samples. Our data suggested that BM-MSCs were not the origin of the gastric cancer cells or their nature might have been totally changed after transforming into cancer cells.

Key words: Gastric cancer, Mesenchymal stem cells, Metaplasia, Dysplasia
\end{abstract}

Received: May12,2019 Accepted: May20,2019

How to cite the article: Mehdi Mohammadi, Ali Jalili, Bahram Nikkhoo, Fardshad Sheikhesmaieli.Prevalence of CD34, CD326 and STRO-1 expression in gastric precancerous and cancer samples: A preliminary study. SJKU 2019; 24 (5): 69-76

Copyright (C) 2018 the Author (s). Published by Kurdistan University of Medical Sciences. This is an open access article distributed under the terms of the Creative Commons Attribution-Non Commercial License 4.0 (CCBY$\mathrm{NC}$ ), where it is permissible to download, share, remix, transform, and buildup the work provided it is properly cited. The work cannot be used commercially without permission from the journal. 


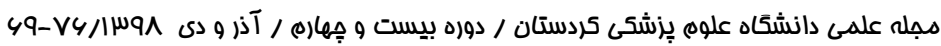

\title{
بررسى فراوانى مار كر هاى CD34،CD236 و STRO-1 در ضايعات بيش سرطانى و سرطان معده: يك مطالعه مقدماتى
}

\author{
مهدى محمدى'، على جليلى 'وا، بهرام نيكخو'، فرشاد شيخ اسماعيلى'

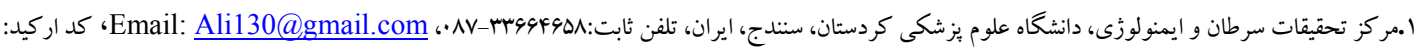 \\ ........r- rیrr_rqr人

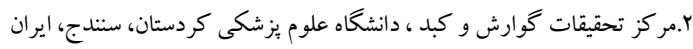

جִكيله

زمينه وهدف: سرطان معده يكى از شايع ترين سرطانهاى جهان و ايران است و عفونت با هليكوبا كتر ييلورى در ايجـاد آن نقش

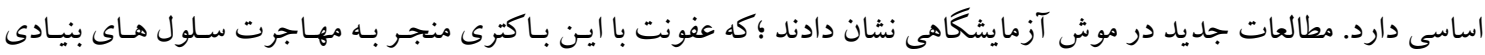

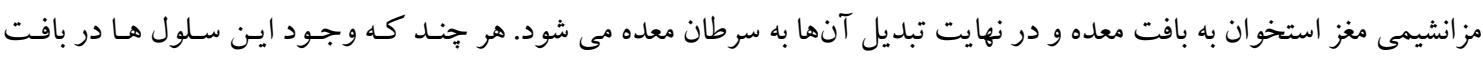

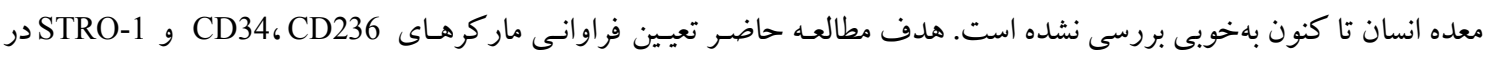
ضايعات بيش سرطانى و سرطان معده بود.

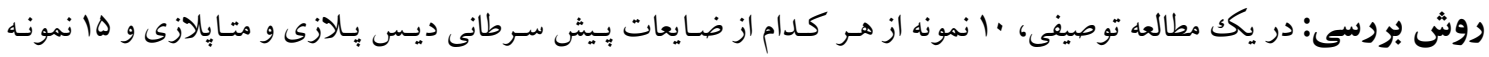

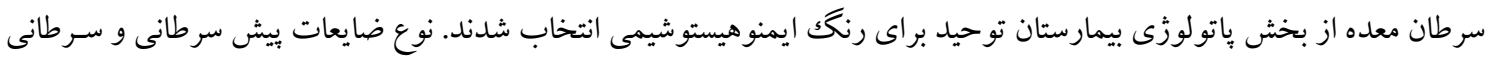

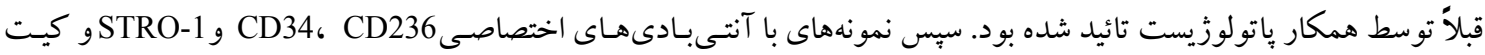

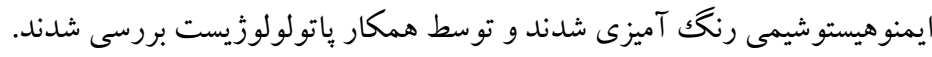

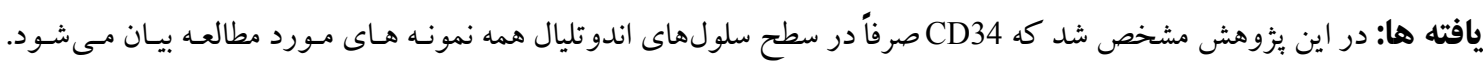

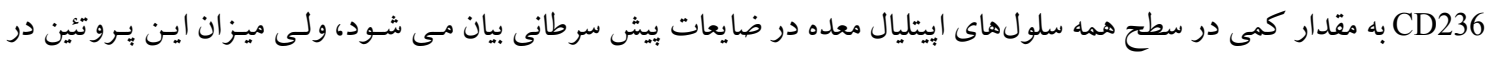

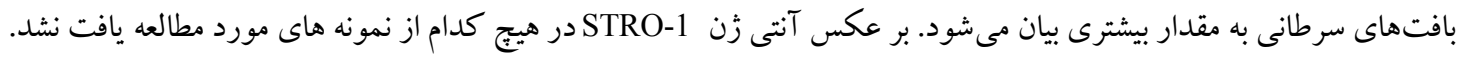

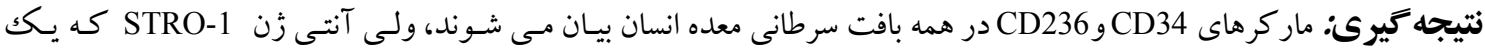

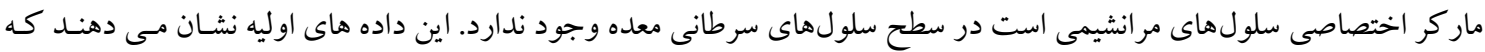

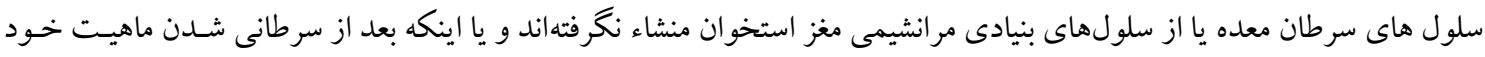
راز از دست مى دهند. كلمات كليدى: سرطان معده، سلولهاى بنيادى مزانشيمى، متإيلازى، ديس بيلازى

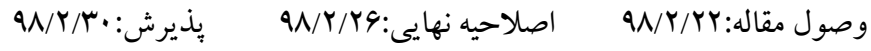


مز انشيمى از جمله سـلول هـاى عضـلانى، غضـروف، سـلول

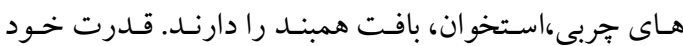
تجديـد شـوندگى(self-renewal) ، عمـر طولانى، توانايى تكثير براى دوره هاى طولانى، مقاومت در برابر آيويتوزيس

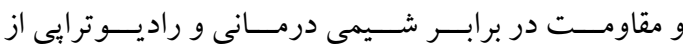
خصوصـيات مهـم ايـن سـلول هـا اسـت(لو 9). سـلولهــاى CDrI، CDrr، CDra،STRO-1 ماركرهـاى MSCs

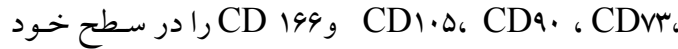

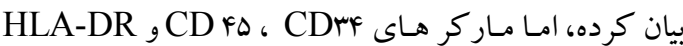
را بيان نمى كنند (ؤو)، بـرعكس سـلولهـاى HSCs داراى مار كرهاى CD Y CDFA هستند و ايـن سلولهـاى بعـد همه سلول هـاى خونى و ايمنى را مسىسـازند (•). بعلاوه سلولهاى اندو تليال عروق نيز ماركر D D ر را بيان مسى كنتـد ولى ماكر CDFA راندارند (11). اخرجه از لحاظ زنتيكى تفاوتهاى قابل توجهى ميان انواع

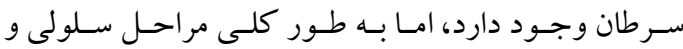
مولكولى دخيل در ايجاد سـرطان و متاستاز تقريبـاً در همـهـ سرطانها مشترك هستند. استروما و محيط ميكرو شيميايى

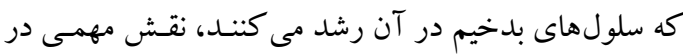
سرطانى شدن سلولها به عهده دارند. همانطور كه هموستاز نرمال بافتى ميان سلولهاى إيتليال و محيط ميكرو شيميايى

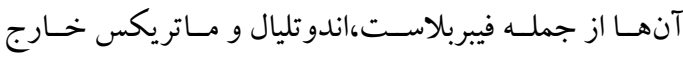
سلولى حفظ مى شـود، در بـــخيمى نيز واكـنش مشابه امـا متضـاد ميـان سـلولهـاى نئوبلاسـيكك و محـيط اسـترومايى

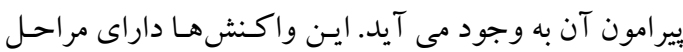

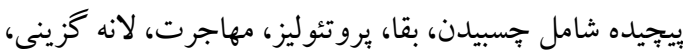

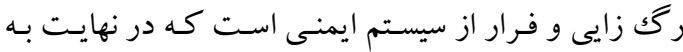

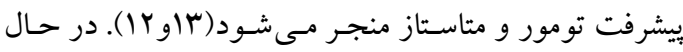
حاضر اطلاعات اندكى در رابطه با تعامل سلولهاى سرطانى مهنى

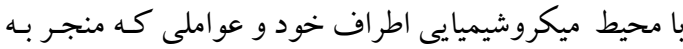
سرطان مى شوند، وجود دارد. بر اين اسـاس مطالعه دربـاره نقش سلولهاى MSCs در ايجاد تومور، ييشرفت تومسور و
مقدمه سرطان معده جهارمين سرطان شايع بوده و بعد از سرطان ريه

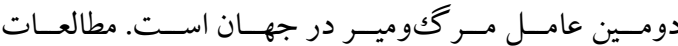
إيدميولوزيكى نشان مى دهند كه در سـال •1.ب تعـداد / 1/ ميليون نفر مورد جديد به اين بيمارى مبتلا شده اند كه .9.9 ايسن مـوارد در كشـورهاى در حـال توسـعه هستـند. در سـال international agency ( 1994 آزانس بين الملى سرطرطان (for research on cancer به عنوان مهم ترين عامل مؤثر در ايجاد سرطان معـده معرفى

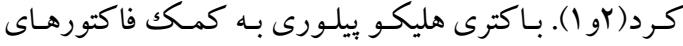
ويرولانس نظير Vac-A و Cag- A Urease در بافـت معــه كلونيزه شده و بـا ايجاد التهاب و آسـيب بـه إيتليوم معـده باعث chronic atrophic gastritis مس شـود. در صورت

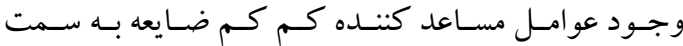
dysplasia ,metaplasia آدنو كارسينوما تبديل شوند(او r).

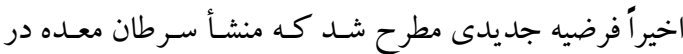
مدل حيو ان آزمايشگاهى سلولهاى مشتق از مغز استخو ان bone marrow-derived mesenchymal stem cells هستيند. ايـن فرضيه باعثث تحولى بزر كُ در (BM-MSC)

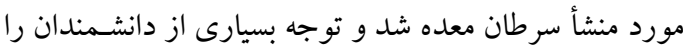
به BM-MSC معطوف كرد. حضور و تجمع ايـن سلول هـا در

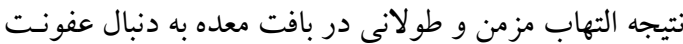

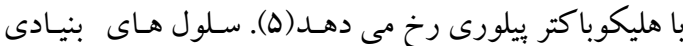

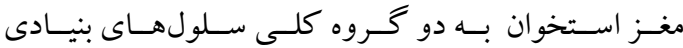
Hematopoietic stem هماتويويتيكك مغـز استخوان و و سلولهاى بنيادى مزانشيمى مغز استخوان تقسيم بندى مي Mesenchymal stem cells (MSCs)

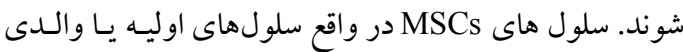
مزوبلاست هستند كه بستر لازم بـراى خونسازى رافراهم مى كنند. تحت شرايط ميكرو شيميايى بافت ها اين سلول هـا هـاكيا

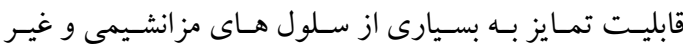


بيمارستان توحيد سنتدج از بين نمونـه هـاى معـده · ا نمونـهـ

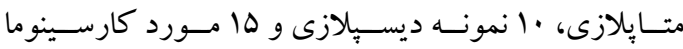
يصورت تصادفى انتخاب شدند. لام ها و بلوكك ها ى آنها استخراج و لام ها بازبينى شدند. در صورت عـدم مناسـب بودن لام ها، برش مجدد و رنگك آميزى هماتو كسيلين و

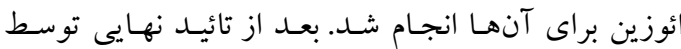
همكار ياتولوزيست، لام هـا علامـت خـذارى شـده و بـراى رنك آميزى ايمنوهيستوشيمى با ماركرهـاى CDY4 ، CDY

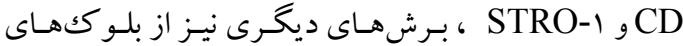
يار افينى كر فته شد.

مطالعات بافتشناسى: بلوك هاى يارافينى مـوارد انتخـاب شده توسط دستخاه ميكروتوم به ضخامت ه ميكرومتر برش دادهشده و همان طورى كه قبلاً گز ارش شده بـود بـهـ روش

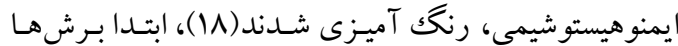
يارافين گيرى ( با استفاده از زايلل · ․ درصد) و آبدهى (با درجات صعودى الكـل و يـك مرحلـه آب مقطر خـالص)

شـده و بعـد از بازيـابى آنتىزن)(Antigen retrieval) توسط بـافر سـيترات (بـه مـدت ها دقيقهـ در بـن مـارى هو درجه)، با محلول بر اكسيد هيدروزن بَ٪ انكوبه شدند. سيس

برشها به صورت جداكانه با آنتى بادى هاى ضد CDHF ،

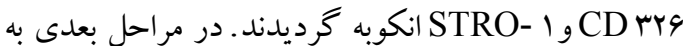
biotinylated link antibody immunoglobulin استفاده كرديد. وجود آنزيم ير اكسيداز بـا كرومـوزن دى آمينوبنزيدين (DAB) نشـان داده شـد. سـبس اسـلايدها بـا

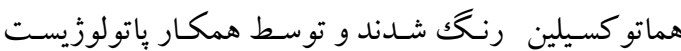
مورد بررسى قرار گرفتند. ضـمنا داده هـاى گحرد آورى شـده با استفاده از فرمولهاى آمار توصيفى دسته بندى شد.

هافته ها

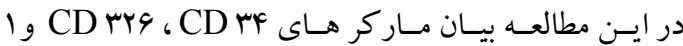
STRO-
متاستاز آن، ضرورى به نظر مى رسد. در بسيارى از تحقيقات

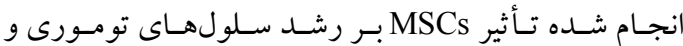
سرطانى شدن آنها، تائيد شده است(هاو \& ). البته اغلب اين مطالعات بر روى مـوش بـوده اسـت و تـا كنـون وجـود ايـن سلولهــا بـهـورت مسـتقيم در بافت سـرطانى معـده انسـان بررسى نشده است. مار كر و CD ك كه در غشاء بسيارى از سـلولهـاى اييتليـالى

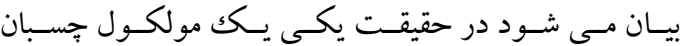
اســت كـــه در بســيارى از (Adhesion Molecule) سرطانهاى بخصوص سلولهـاى سـرطانى اييتليـالى افز ايش بيان دارد. به همين دليل از اين مـاركر بـراى شناسـايى سـلول هاى سرطانى انتشار يافته به گردش خون و همجنين تشخيص متاستاز يا عود مجدد سرطان استفاده مسى شـود(19)، مـاركر CD MF • ال كيلودالتون است كه در ابتدا به عنوان ماركر يسيش سـاز سلول هاى خون ساز انسانى شـناخته شـد؛ امـا در يـيش سـاز سلولهاى اندوتليال نيز بيان مى شود( (او · (1). ماهيـت مـاكر

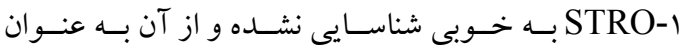
مار كرى براى جداسازى و تشخيص سـلول هـاى MSCs در بافت هاى مختلف به ويـرّه بافت هـاى دنـدانى استفاده مى شود(IV,9) از آنجا كـه اطلاعـات جديــ منشـأ سـلولهـاى سـرطانى را سـلولهـاى BMDCs مز انشـيمى مشـتق از مغـز استخوان مى دانند در اين مطالعه اوليـه از وبr CD بـهعنوان ماكر سلولهاى اييتليال، از F CD بهعنوان ماكر سلولهـاى

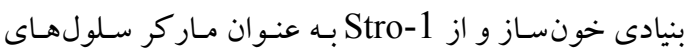
مرانشيمى استفاده شد تاو جود هر كدام از سلولهاى ياد شده را در نمونه هاى متايلازى، ديسيلازى و سرطان معده بررسى كردند.

روش جمـع آورى نمونسه: در يـك مطالعه توصسيفى، بـراى

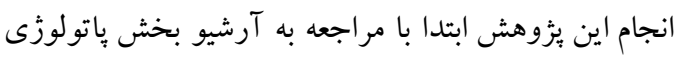


جدول Y. فراوانى بيان مار كر فراوانى بيان ماركر CDrY9 در نمونه هاى متإيلازى، ديس بِلازى و سرطان معده

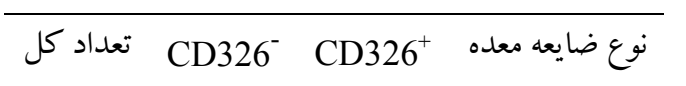

\begin{tabular}{cccc}
\hline 1. & $\cdot$ & 1 & متإيلازى \\
\hline 1. & $\cdot$ & 1. & \\
\hline 10 & $\cdot$ & 10 & \\
\hline
\end{tabular}

جدول بـ - فراوانى بيان ماركر فراوانى بيـان مـاركر Stro-1 در نمونه هاى متإيلازى، ديس بِلازى و سرطان معده

\begin{tabular}{|c|c|c|c|}
\hline تعداد كل & Strol $^{-}$ & Strol $^{+}$ & نوع ضايعه معده \\
\hline 1. & 1. & • & متابِلازى \\
\hline 1. & 1. & . & ديس بِازى \\
\hline 10 & 1. & . & سرطان معده \\
\hline
\end{tabular}

\section{بحث}

عفونت هليكوبـاكتر ييلو رىى در ايجـاد سـرطان معـده نقـش

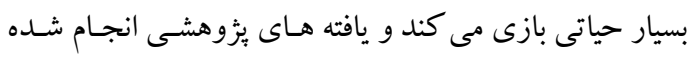

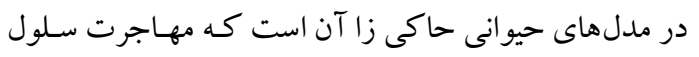

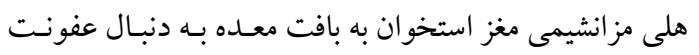

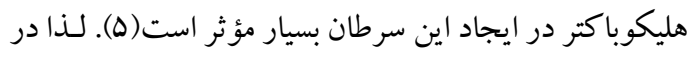

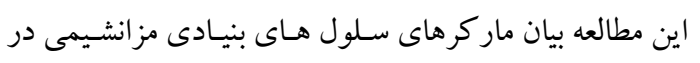

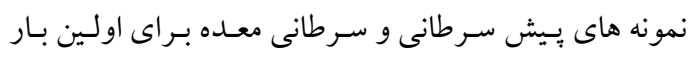

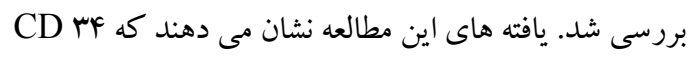

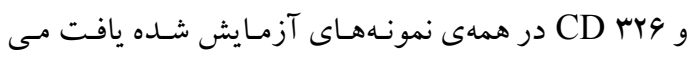
شوند ولى مار كر اختصاصى سلول هـاى مزانشيمى انسـان در

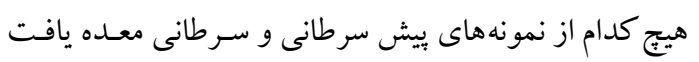
نشد.
ديس بِلازى بررسى شدند و همـان طورى كـه در جـدول 1

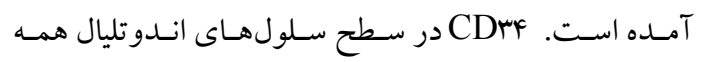

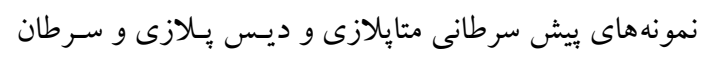

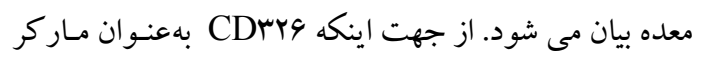

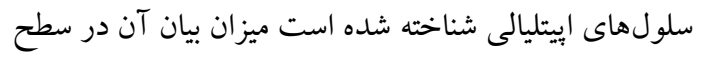
نمونه هاى متإيلازى، ديس هِلازى و سرطان معده بررسى شد

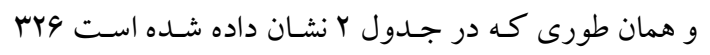

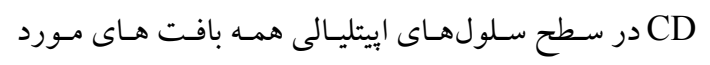

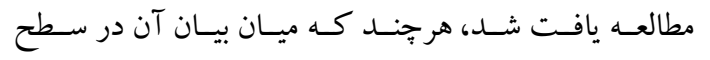

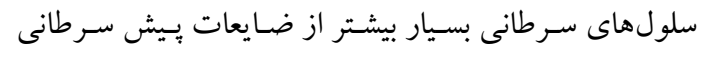
متإيلازى و ديس بِلازى بود.

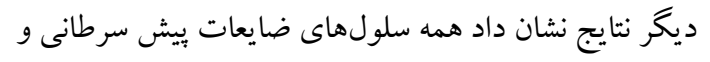
سرطان معده، فاقد Stro-1 بودند (جدول r). جدول 1. فراوانى بيان مار كر فراوانى بيان مـار كر ع CD در

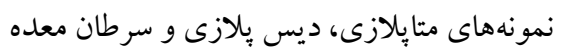

\begin{tabular}{|c|c|c|c|}
\hline تعداد كل & CD34- & $\mathrm{CD} 4^{+}$ & نوع ضايعه معده \\
\hline 1. & . & 1. & متإِلازى \\
\hline 1. & . & 1. & ديس بِلازى \\
\hline 10 & . & 10 & سرطان معده \\
\hline
\end{tabular}


ركى زايسى در بافت بخصـوص بافـت سـرطانى بيشـتر باشـــ

$$
\text { مقدار بيان CD MF هم بيشتر خواهد بود. }
$$

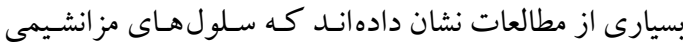
مغـز اسـتخوان هميشـه بـهـ بافـت هـا و اركـان هـاى آسـيب مهاجرت مى كنند تا درترميم آن بافـت مـؤثر باشــد(YF). از

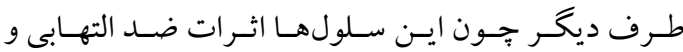
ايمنومدولاتورى دارند براى كاهش شدت التهاب بـه بافت هاى ملتهب هم مهاجرت مى كند(YD). با اين وجـود در سـال F F ب براى اولين بار نشان داده شد كه به دنبال عفونت مزمن با هليكوبا كتر ييلورى اين سلول هاى مز انشيمى مغز استخوان وارد بافت إيتليالى معده شده و تبديل به سلول هاى سـرطانى مى شوند هر جند كه اين مسـئله در عفونست حساد بـا هليكـو باكتر ديده نشد. ابن بافته ايـن فرضسيه را مطرح مسى كنـد كـه سلولهاى مزانشـيمى بـراى تـرميم و يـا كـاهش التهـاب وارد بافت ملتهب معده مسى شـوند ولى بـه دليـل التهابـ مـزمن و همجنين مدياتورهاى شيميايى توليد شده در اين التهاب ايـن سلول ها به سلول هاى سرطانى تبديل مى شوند(ه). در همين

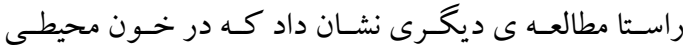
بيمار ان مبتلا به سـرطان معــده سـلول هـاى بنيـادى خونسـاز همجينين سلول هاى بنيادى مز انشـيمى (CD13+/CD45+) يافت شد. بر عكس اين سـلول هـا در (CD45-/Stro-1+) خون ميحطى بيمار ان مبتلا به سرطان هاى استرومايى دستگاه كوارش و تومورهاى نورواندكرين مشـاهده نشـد(Y). هـر جند كه يُزوهش هاى ياد شده همخً دلالت بر نقش سـلول هاى مز انشيمى مغز استخوان در سرطان معـده دارنــد ولى تـا كنون مطالعه اي انجام نشده است تا اين سلول ها را در بافـت ستر هاى بيش سرطانى و سرطان معده انسان مـورد بررسى قرار

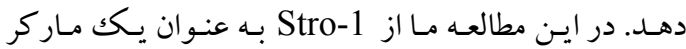
اختصاصى سلول هـاى مز انشـيمى مغـز اسـتخوان وجـود ايـن سلول ها را بررسى كـرديم ولى هـيج كـدام از نمونسه هـاى مورد مطالعه آنتى زن ا Stro را بيان نمى كردند .
مطالعات متعددى نشان دادهانـد كـه CD Tr بـ روى غشـا سلولى ،سلول هاى إيتيالى بيان مى شود و نسـبت بيـان آن بـا تمـايز سـلولى نسـبت عكس دارد؛ بنـابراين در سـرطانهـاى سـلولهـاى اييتليـال مقــدار بيـان ايـن مولكـول در قيـاس بــه

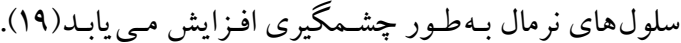
همجِنين Joo M و همكـاران نشـان دادندكه وبr CD در بافت هاى متايلازى، ديس بِلازى و ادنو كار سنو ما معـده بيـان مـى شـود و ميـزان بيـان آن بــا رتبـهبنــــى يــاتولوزى نسـبت مسـتقيم دارد ولى (pathological grading) ارتباطى بين Stage بيمـارى و متاسـتاز نــدارد(19). در تائيـد اين يافتها ما اخيراً گزارش كرديم كه ميزان بيـان צr CD ارتباطى با طول عمر بيماران مبتلا به سرطان معده نـدارد •(Y) از طرف ديخر در مطالعه كنونى ما مشاهده كرديم نه تنها در همه ى نمونه هاى بيش سرطانى همانـــ متـايلازى و ديس بِازى بيان مى شود بلكه در نمونه هلى سرطان معـده هم بيان مى شود كه يافته هاى قبلى(19) را تائيد مى كند .

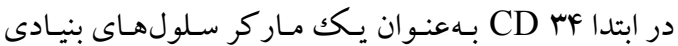
خون ساز شناخته شـــ كـه باعـث اتصـال ايـن سـلول هـاى بـهـ

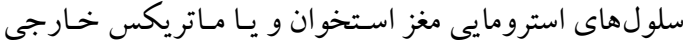
سـلول مغـز اسـتخوان رافـراهم مسى كنـد. اكر جـهـه در آغـاز

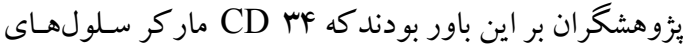
بنيادى خـون سـاز اسـت ولى بعـاً نشـان داده شـد كـه ايسن مولكــول در ســطح بسـيارى از سـلولهــاى ديخــــ يافـت

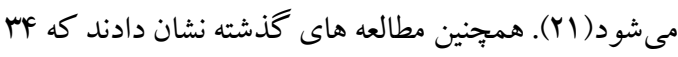
CD در سلولهاى اندوتليال سرطان معـده بيـان مسى شـود و ميز ان بيان آن نسبت مستقيم با ميران توليد اينترلو كين هشـت

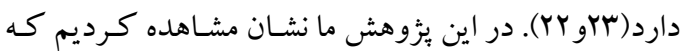
در F CD سطح سلولهاى اندوتليال ضايعات يِش سرطانى متإِلازى، ديس بِازى و سرطان معده بيان مسى شـود و همـــ

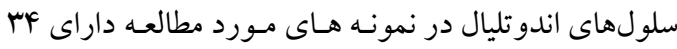
هستند؛ بنابر اين مىتوان نتيجـه كرفت كـه ع CD سطح همه سلول هـاى انـدوتليال جـود دارد و هـر جـهـ مقـدار

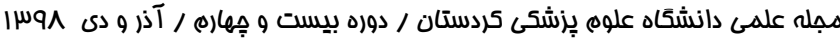




$$
\begin{aligned}
& \text { دست بدهند. البته نمى توان اين حقيقت را بنهان كرد كه نـه }
\end{aligned}
$$

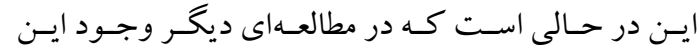

$$
\begin{aligned}
& \text { تنها فر آيند سـرطانى شـدن در انسـان و مـوش آزمايشكاهى النى }
\end{aligned}
$$

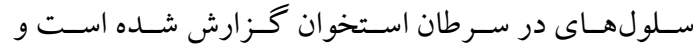

$$
\begin{aligned}
& \text { بسيار متفاوت است و از طرف ديخر تعداد نمونه هاى كه مـا } \\
& \text { سلولهاى Stro1+ در قياس با سلولهايى كه اين ماركر را } \\
& \text { در اين مطالعه استفاده كرديم بسيار كم بودند و نمى توان بر } \\
& \text { ندارند قدرت تكثير و مقاومـت دارويس بيشترى را از خود }
\end{aligned}
$$

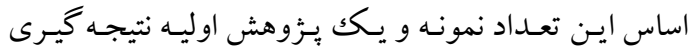

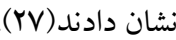

$$
\begin{aligned}
& \text { نهايى كرد. } \\
& \text { نتيجه كيرى } \\
& \text { هر جند كه بر اساس اين يافته هاى ما نتوانستيم اين سلولهـا } \\
& \text { تشكر و قدردانى } \\
& \text { را در بافتهاى مورد مطالعه شناسايى كنيم ولى دليل بـر اين } \\
& \text { نويسـند كان ايـن مقاله از معاونـت يُزوهشى دانشــاه علـوم } \\
& \text { نيست كه اين سلولهـا در ايـن فر آينـد سـرطانى شـدن معـده }
\end{aligned}
$$

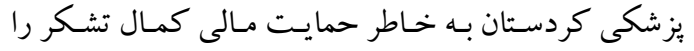

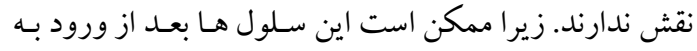

$$
\begin{aligned}
& \text { دارند. } \\
& \text { معده تحت فر آيند التهاب مزمن به سلول هاى إيتليالى تبديل }
\end{aligned}
$$

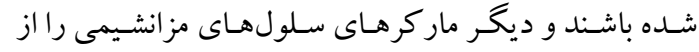

\section{Reference}

1. Lyon F. IARC monographs on the evaluation of carcinogenic risks to humans. Some industrial chemicals. 1994;60:389-433.

2. Asaka M, Sepulveda AR, Sugiyama T, Graham DY. Gastric Cancer. In: Mobley HLT, Mendz GL, Hazell SL, editors. Helicobacter pylori: Physiology and Genetics. Washington (DC): ASM Press

ASM Press.; 2001.

3. Wang F, Meng W, Wang B, Qiao L. Helicobacter pylori-induced gastric inflammation and gastric cancer. Cancer letters. 2014;345(2):196-202.

4. Zhou CB, Fang JY. The role of inflammatory programmed cell death in gastrointestinal cancer and immune responses to intestinal microbial infection. Biochimica et biophysica acta Reviews on cancer. 2019.

5. Houghton J, Stoicov C, Nomura S, Rogers AB, Carlson J, Li H, et al. Gastric cancer originating from bone marrow-derived cells. Science (New York, NY). 2004;306(5701):156871.

6. Andrzejewska A, Lukomska B, Janowski M. Concise Review: Mesenchymal Stem Cells: From Roots to Boost. Stem Cells. 2019.

7. Viswanathan C, Kulkarni R, Bopardikar A, Ramdasi S. Significance of CD34 Negative Hematopoietic Stem Cells and CD34 Positive Mesenchymal Stem Cells - A Valuable Dimension to the Current Understanding. Current stem cell research \& therapy. 2017;12(6):476-83.

8. Lv F-J, Tuan RS, Cheung KM, Leung VY. Concise review: the surface markers and identity of human mesenchymal stem cells. Stem cells. 2014;32(6):1408-19.

9. Zhang Y, Zhao D, Tian C, Li F, Li X, Zhang L, et al. Stro-1-positive human mesenchymal stem cells prolong skin graft survival in mice. Transplantation proceedings. 2013;45(2):726-9. 10. Garg S, Madkaikar M, Ghosh K. Investigating cell surface markers on normal hematopoietic stem cells in three different niche conditions. International journal of stem cells. 2013;6(2):129. 
براسى فراوانى sاركر هاى... V4

11. Benyamine A, Magalon J, Cointe S, Lacroix R, Arnaud L, Bardin N, et al. Increased serum levels of fractalkine and mobilisation of CD34+ CD45- endothelial progenitor cells in systemic sclerosis. Arthritis research \& therapy. 2017;19(1):60.

12. Wang M, Zhao J, Zhang L, Wei F, Lian Y, Wu Y, et al. Role of tumor microenvironment in tumorigenesis. Journal of Cancer. 2017;8(5):761.

13. Schedin P, Elias A. Multistep tumorigenesis and the microenvironment. Breast cancer research. 2004;6(2):93.

14. Bergfeld SA, DeClerck YA. Bone marrow-derived mesenchymal stem cells and the tumor microenvironment. Cancer and Metastasis Reviews. 2010;29(2):249-61.

15. Liu S, Ginestier C, Ou SJ, Clouthier SG, Patel SH, Monville F, et al. Breast cancer stem cells are regulated by mesenchymal stem cells through cytokine networks. Cancer research. 2011;71(2):614-24.

16. Joo M, Kim H, Kim MK, Yu HJ, Kim JP. Expression of Ep-CAM in intestinal metaplasia, gastric epithelial dysplasia and gastric adenocarcinoma. Journal of gastroenterology and hepatology. 2005;20(7):1039-45.

17. Williams EL, White K, Oreffo RO. Isolation and enrichment of Stro-1 immunoselected mesenchymal stem cells from adult human bone marrow. Stem Cell Niche: Springer; 2013. p. 67-73.

18. Nikkhoo B, Jalili A, Fakhari S, Sheikhesmaili F, Fathi F, Rooshani D, et al. Nuclear pattern of CXCR4 expression is associated with a better overall survival in patients with gastric cancer. Journal of oncology. 2014;2014:808012.

19. Kroepil F, Dulian A, Vallbohmer D, Geddert H, Krieg A, Vay C, et al. High EpCAM expression is linked to proliferation and lauren classification in gastric cancer. BMC research notes. 2013;6:253.

20. Mohammadi M, Jalili A, Nikkhoo B, Roshani D, Tari K, Sheikhesmaili F. Overexpression of epithelial cell adhesion molecule (EpCAM) in gastric cancer and its correlation with overall survival of the patients. Chronic Diseases Journal. 2019;7(1):49-52.

21. Sidney LE, Branch MJ, Dunphy SE, Dua HS, Hopkinson A. Concise review: evidence for CD34 as a common marker for diverse progenitors. Stem cells. 2014;32(6):1380-9.

22. Tenderenda M, Rutkowski P, Jesionek-Kupnicka D, Kubiak R. Expression of CD34 in gastric cancer and its correlation with histology, stage, proliferation activity, p53 expression and apoptotic index. Pathology Oncology Research. 2001;7(2):129-34.

23. Nakayama H, Enzan H, Miyazaki E, Kuroda N, Naruse K, Kiyoku H, et al. CD34 positive stromal cells in gastric adenocarcinomas. Journal of clinical pathology. 2001;54(11):846-8.

24. Caplan AI, Correa D. The MSC: an injury drugstore. Cell stem cell. 2011;9(1):11-5. 25. Ben-Ami E, Berrih-Aknin S, Miller A. Mesenchymal stem cells as an immunomodulatory therapeutic strategy for autoimmune diseases. Autoimmunity reviews. 2011;10(7):410-5.

26. Błogowski W, Zuba-Surma E, Sałata D, Budkowska M, Dołęgowska B, Starzyńska T. Peripheral trafficking of bone-marrow-derived stem cells in patients with different types of gastric neoplasms. Oncoimmunology. 2016;5(4):e1099798.

27. Lan J, Liu X, Rong W, Wei F, Jiang L, Yu H, et al. Stro-1(+) stromal cells have stem-like features in giant cell tumor of bone. Journal of surgical oncology. 2012;106(7):826-36.

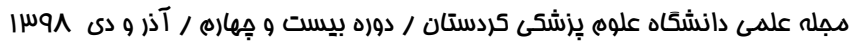

